\title{
Occurrence of Lace bug Vatiga illudens and Vatiga manihotae (Hemiptera: Tingidae) in Mato Grosso do Sul, midwestern Brazil
}

\author{
PATRÍCIA P. BELLON ${ }^{1}$, ANA P.G.S. WENGRAT ${ }^{2}$, SAMIR O. KASSAB ${ }^{1}$, \\ VANDA PIETROWSKI ${ }^{2}$ and ELISÂNGELA S. LOUREIRO ${ }^{3}$ \\ ${ }^{1}$ Programa de Pós-Graduação em Entomologia e Conservação da Biodiversidade, \\ Faculdade de Ciências Biológicas e Ambientais (FCBA), Universidade Federal da Grande Dourados (UFGD), \\ Rodovia Dourado-Itahum, Km 12, Caixa Postal 533, 79804-070 Dourados, MS, Brasil \\ ${ }^{2}$ Centro de Ciências Agrárias, UNIOESTE, Rua Pernambuco, 1777, 85960-000 Marechal Cândido Rondon, PR, Brasil \\ ${ }^{3}$ Universidade Federal de Mato Grosso do Sul (UFMS), Campus de Chapadão do Sul (CPCS), \\ Antiga Estrada da Fazenda Campo Bom, Caixa Postal 112, 79560-000 Chapadão do Sul, MS, Brasil
}

Manuscript received on September 9, 2010; Accepted for publication on December 16, 2010

\begin{abstract}
Nymphs and adults of the lace bug (Hemiptera: Tingidae) have been found in cassava crops (Manihot esculenta) in Mato Grosso do Sul State, Brazil. The insects were collected in the field and taken to the laboratory where they were identified based on some morphological traits of the species Vatiga manihotae (Drake) and $V$. illudens (Drake), which are first reported in the aforementioned state.
\end{abstract}

Key words: Insecta, Manihot esculenta, lace bug, registration.

\section{INTRODUCTION}

The cassava culture (Manihot esculenta Crantz) presents a huge socio-economical importance for the South-Central region of Brazil. Its tuberous root production is cultivated as a source of human food and for the starch industry (Gómez et al. 2006).

Despite its rusticity, this culture is affected by pests that can cause significant damages and losses for the farmers (Farias and Bellotti 2006). The studies on the entomofauna associated to cassava in Brazil consider the sphingids (Erinnyis ello) (Lepidoptera: Sphingidae) as the main pest of this crop (Pietrowski 2009). However, it has been noticed that there has been an increasing incidence

Correspondence to: Patrícia Paula Bellon

E-mail: phatriciabellon@yahoo.com.br regarding lace bugs, Vatiga manihotae (Drake) and V. illudens (Drake) (Hemiptera: Tingidae), in the last five years, which is a very serious concern aspect for cassava farmers. Thus, there is an urgent need to raise information from research departments and technical assistance (Pietrowski 2009).

Froeschener (1993) identified several species of Vatiga, highlighting manihotae and illudens as the most important in the cassava culture. $V$. illudens is predominant in Northeast Brazil, but it is also reported in the Caribbean and Florida region; $V$. manihotae is reported mainly in Colombia and Venezuela, as well as in Cuba, Peru, Equator, Paraguay, Argentina and Brazil (Bellotti et al. 1999, Bellotti 2000). However, lace bugs species related to the cassava culture have not been identified up to now in the state of Mato Grosso do Sul. 
Nymphs and adults of lace bugs are fed by cell protoplast of leaf parenchyma and, consequently, clorotic spots are left on the upper surface of leaves, which may develop to red-brown spots (Bellotti et al. 1999). This damage caused by the pest can reduce the plant photosynthesis and, consequently, early leaf drop may occur, as well as a complete defoliation in case of severe infestation (Bellotti et al. 2002).

Some samples of lace bugs were taken from commercial fields in the cities of Angelica and
Dourados, Mato Grosso do Sul State. These insects were stored in Eppendorf tubes with a 70\% alcohol solution and sent to the Entomology Laboratory of University of Paraná - UNIOESTE, where they were identified to the species level by using the morphological aspects described by Froeschener (1993).

Based on head morphological traits, the amount and disposition of thorns and tubercles, tissue color and reticle aspects, the lace bug species $V$. manihotae and $V$. illudens could be confirmed (Figure 1).

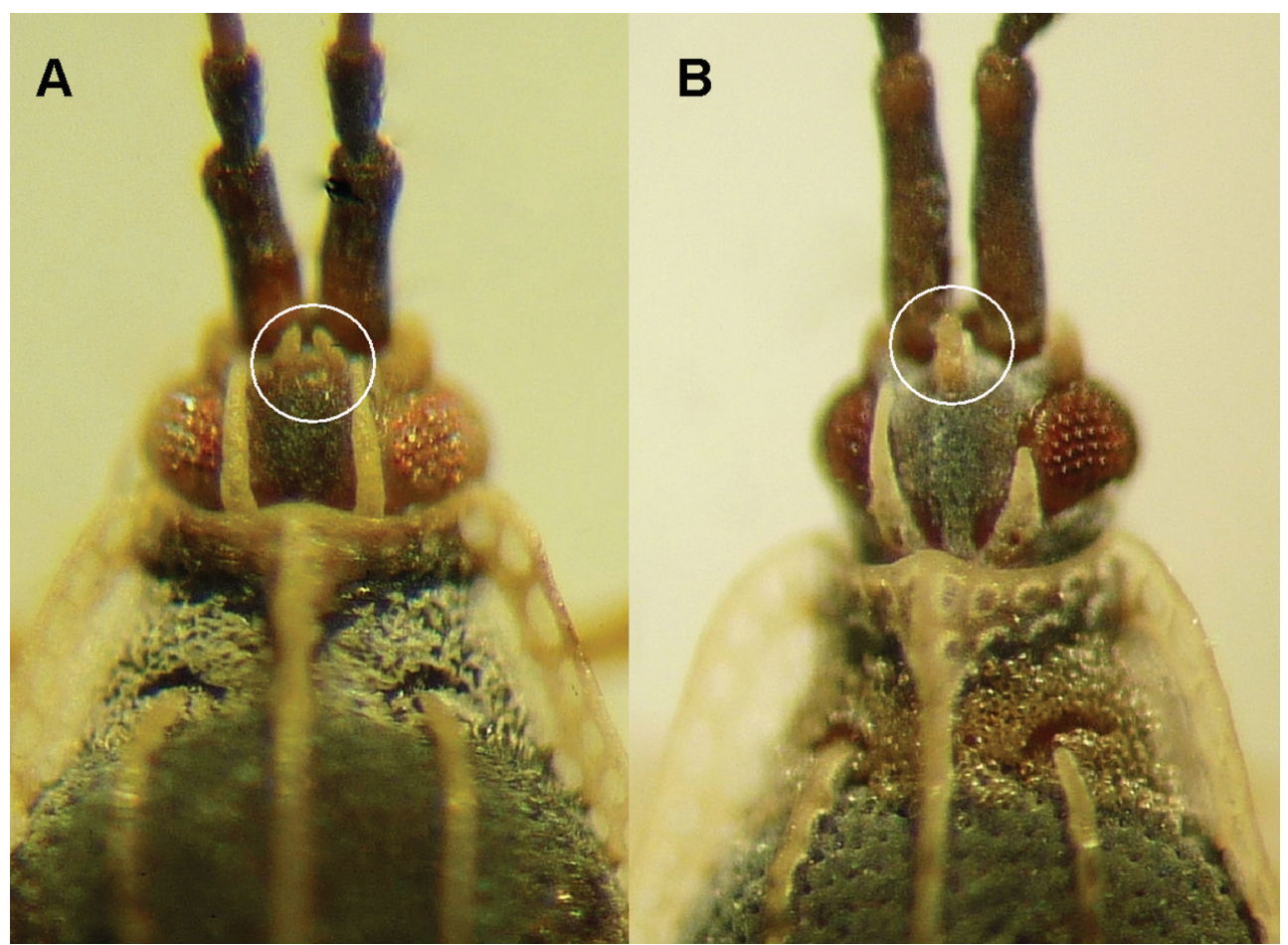

Fig. 1 - Dorsal view of lace bug species of cassava crops. Note the presence of small thorns at the anterior angle of the head near the antennas on Vatiga illudens (A) and a single central thorn in Vatiga manihotae (B).

Lace bug species reported by this study in the cassava culture in fields in the state of Mato Grosso do Sul, besides presenting potential damages and outbreaks, show a need for further studies regarding an integrated management for species control because once a growth of the cassava cultivated areas may be expected in the state.

\section{RESUMO}

Ninfas e adultos do percevejo-de-renda (Hemiptera: Tingidae) foram encontrados em lavouras de mandioca (Manihot esculenta) no Estado do Mato Grosso do Sul, Brasil. Os insetos foram coletados em campo e levados ao laboratório, onde foram identificados com base em algumas características morfológicas nas espécies 
Vatiga manihotae (Drake) e V. illudens (Drake), os quais são registrados pela primeira vez no Estado mencionado.

Palavras-chave: Insecta, Manihot esculenta, percevejode-renda, registro.

\section{REFERENCES}

Bellotti AC. 2000. El manejo integrado de las plagas principales en el cultivo de la yuca. In: INTERNATIONAL COURSE-WORKSHOP ON BIOLOGICAL CONTROL, Cali, p. 1-35.

Bellotti AC, Arias BV, Vargas OH and Peña JE. 2002. Pérdidas en rendimiento del cultivo de yuca causadas por insectos y acaros. In: LA YUCA EN EL TERCER MILENIO: SISTEMAS MODERNOS DE PRODUCCIÓN, PROCESAMIENTO, UTILIZACION Y COMERCIALIZACIÓN, Ciat/Clayuca, p. 327-586.
BeLlotTI AC, SMITH L AND LAPOINTE S. 1999. Recent advances in cassava pest management. Annu Rev Entomol 44: 343-370.

FARIAS ARN AND BELlOTTI AC. 2006. Pragas e seu controle. In: ASPECTOS SOCIOECONÔMICOS E AGRONÔMICOS DA MANDIOCA. Cruz das Almas: Embrapa Mandioca e Fruticultura Tropical, p. 591-671.

FROESCHENER RC. 1993. The neotropical lace bugs of the genus Vatiga (Heteroptera:Tingidae), pests of cassava: New synonymies and Key to Species. Proc Entomol. Soc Wash 3: 457-462.

GÓMEZ SA, ROHDEN V DA S, DUARTE MM AND ARCE CCM. 2006. Entomofauna associada a cultura da mandioca na região sul de Mato Grosso do Sul. Embrapa 1: 7-27.

PIETROWSKI V. 2009. Pragas da cultura da mandioca: percevejo de renda e cochonilhas. CERAT - Botucatu. Revista Raízes e Amidos Tropicais (Online). Palestras, 2009 5: 84-93. Disponível em: http://www.cerat.unesp.br/xiiicbm/index. html. Acesso 13 Jan. 2010. 